JOHN FITCH'S STEAMBOAT EXPERIMENT ON COLLECT formations of form, but are developed directly from the egg of these Malacobdellce alive, and being of an inquiring mind POND.* The population of New York city had nearly doubled in the leech is always in proportion to that of the natural to admit that they were very nice, very palatable, and of the ten years since 1786. Streets had been laid out, and "bost" or victim on which they prey, as, for instance, our the most desirable Little Neck clam flavor, from which babitations erected above the swampy fields in the region of mollusks afford safe harbor and food to various marine bighly prized brand of clams they were taken.

Canal street. But although surveys bad been made of the leeches which are much lower in development than those The Chinese eat both marine and fresh-water leeches. several streets about the Collect, or Fresh Water Pond, they $\mid \begin{aligned} & \text { found on fishes, reptiles, and mammals. } \\ & \text { That the leech is very sensitive to all atmospheric changes }\end{aligned}$

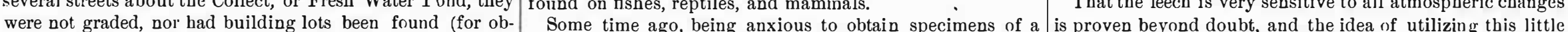
were not graded, nor had building lots been found (for ob- Some time ago, being anxious to obtain specimens of a is proven beyond doubt, and the idea of utilizing this little
vious reasons) marketable in that locality. The water of leech common in our bard clams, I applied to the "opener" creature as a sort of barometer is not new. The best leech the pond was sixty feet deep, and the marshy ground to of one of the most fashionable oyster and clam saloons of storm-glass consists of a tall candy jar with tin top, in which the norlhwest, as well as toward the East River, gave little signs of promise as to This beautiful pond, occupying present $\mathrm{great}$ gloomy pile of prison buildings known as the Tombs, was the scene, in the summer of 1796 , of the trial of a boat propelled by steam. It was the inven. tion of John Fitch. The hoat was 18 feet in length and 6 feet beam, with square stern, round bows, and eats. The boiler was a ten or twelve gallon iron pot.

The little craft passed round the poud several times, and was believed capable of making six miles an hour. The spectacle

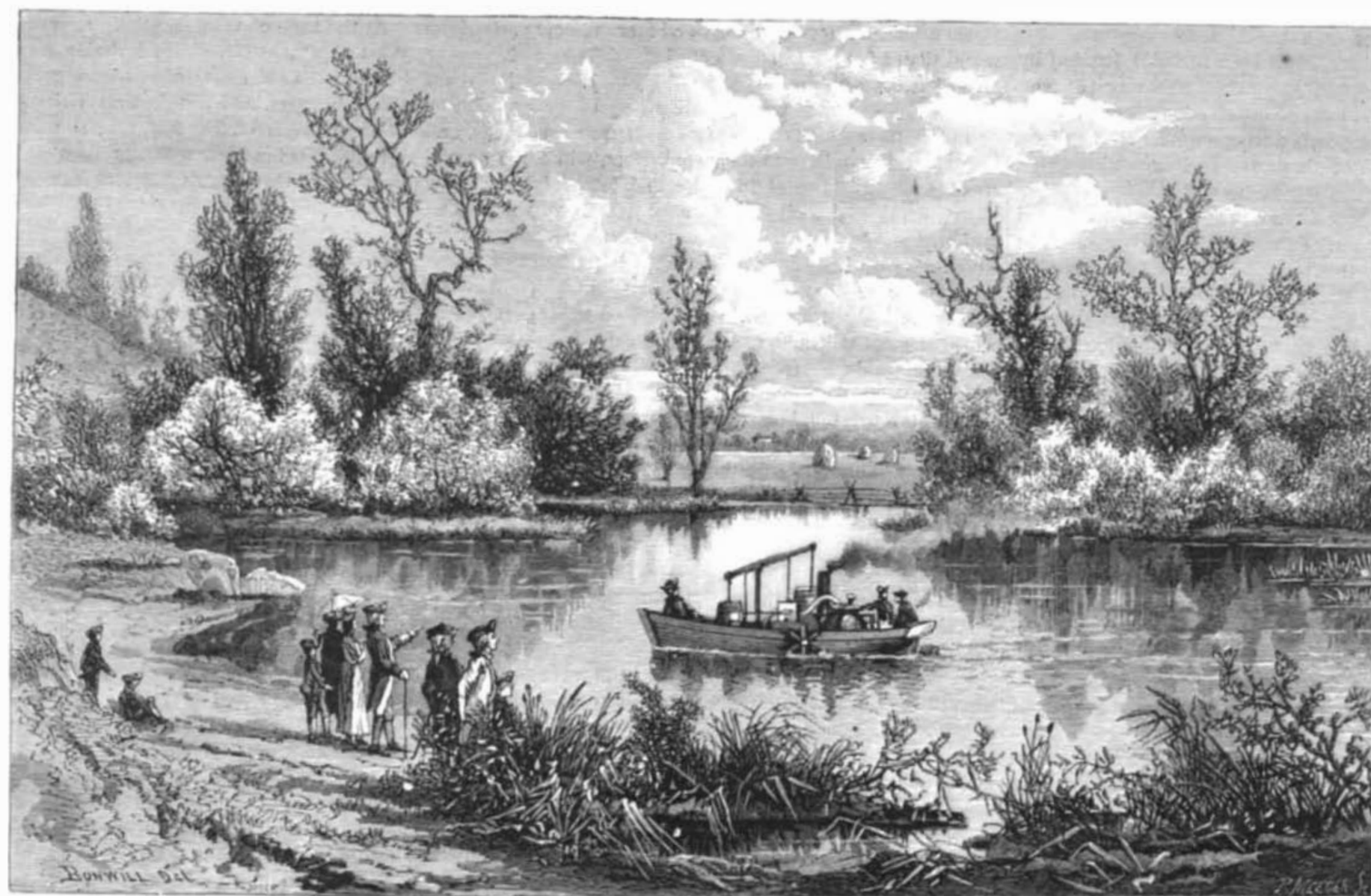

JOHN FITCH'S STEAMBOAT EXPERIMENT ON COLLECT POND NEW YORK CITY 1796. perforations are made; at the bot. tom of the jar a with two or three smooth stones is placed; the jar is then filled with soft water, into has settled and become quite clear, two or dicinal leeches are placed; great care must be aken in summer time to keep the temperature of he water down by placing the shady situation, as beat is fatal to leeches. When the weather con tinues screneand beautiful, the motionless at the motionless at the approach of a rain or snow storm the leechat the top of the water, w b e r they will remain

with critical interest by Chancellor Livingston, Nicholas |Fulton Market to save me some, leaving a bottle of alcohol till the weather becomes settled. When a wind storm is Roosevelt, John Stevens, and others, who had in commo with him. Calling after the expiration of two weeks, I pproaching the leeches will gallop about with great liveli-

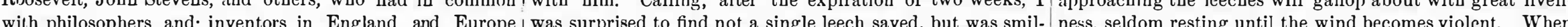
been for some time engaged in the speculative study of the ingly referred to the proprietor, who, I found, had given a thunderstorm is approaching the leeches will seek a lodgsteam engine and'its prospective uses. $\nmid$ Fitch belonged to instructions not to save any for me, as be feared I was one ment above water, displaying great uneasiness, and movin the prominent Connecticut family of that name, was born of those newspaper "sketchists," working up a sensational in convulsive-like threads. In clear frosts, as in dry weather, in the famous old town of Windsor, adjoining Hartford, and article on bard clam trichinæ. These clam leeches are flat, the leeches remain constantly at the bottom. The wate had been inventing and experimenting for a dozen or more an inch in length, and a quarter of an inch in breadth, and must be changed evcry two weeks. The leeches are fed years, hoping to succeed in the application of steam power are attached to the outer wall of the stomach of the clam, twice a year on blood tied in a thin linen bag, or on a living to navigation. His genius, idiosyncrasies, and impecuniosi- which they resemble in color. Having great friendship for frog. The best leeches in the market are Russian and Swety were in perpetual conflict. otherwise he might have the hard clam. I must have swallowed alive many h:ndreds dish, and are of a dark brown color. The Hungarian leech achieved the triumph to which be aspired. He was a man of striking figure, six feet two inches in heigltt, erect and full, his head slightly bald but not gray, altbough fiftythree years of age, and dignified an distant in his general behavior.

\section{LEECH FARMING.}

\section{BY A. W. ROBERTS.}

All leeches are not aquatic. In Ceylon there exists a small variety of leech that attaches itself to the brush and stones which it resenbies in color. Here they hang on, in wait for any passing traveler, con stantly reaching forth with their distended bodies in all directions, great is thes anxiety to attac great is their anxiety to attach Hoffmeister, when collecting on th Island of Ceylon, discovered that his legs were covered with streaks of blood which flowed from hundreds f minte wounds produced by the of micute wound produced by the bites of a terrestrial leech, Hirud ceylonica. This same leech is found
on the Himalaya Mountains, eleven thousand feet above the level of the sea. Several varieties of land leeche also exist in Japan, Chili, and Brazil.

Leeches drink the blood of their victims, and when gorged to the very lips falloff, and do not partake of food again for many weeks.

Leeches do not undergo any trans-

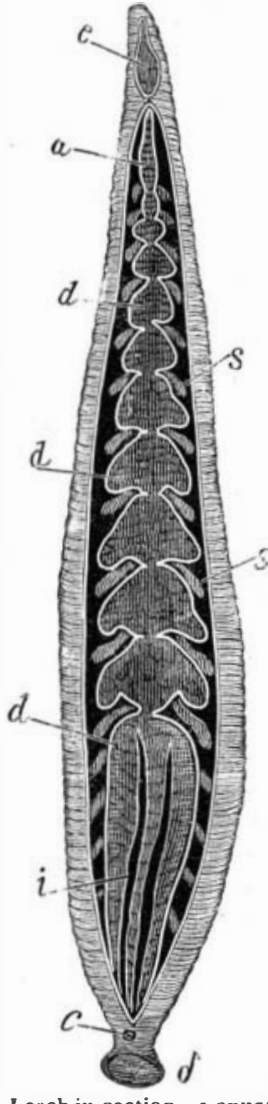

Lecch in section $-c$, anus: $h$, po terior sucker $; \delta 8$, gla layds of
the skin $; i$, intestine $; a$, cesothe skin ; $i$, inteetine : $a$, ceso-
phagus ; $d d d$. stomach ; $e$,

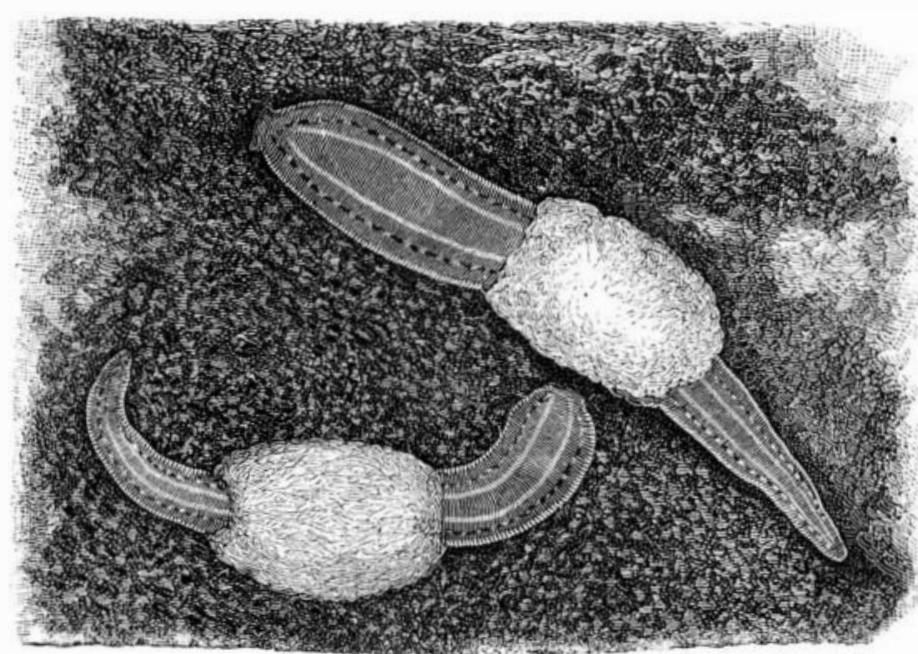

Leeches depositing egge in coconns, in section of peat.

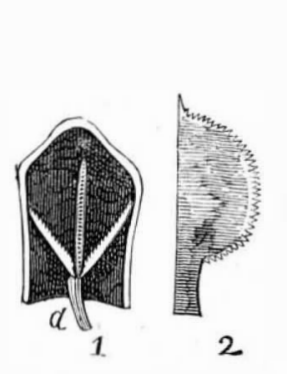

Jaw of a leech.

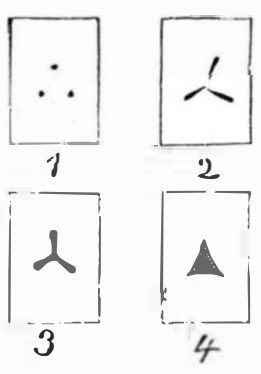

Different forms of the
bite of a leecn.

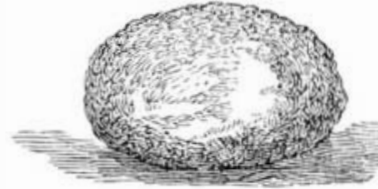

Cocoon of leech closed. is green in color, with yellow stripes, closely resembling ou r horse leech. In Pennsylvania a native leech bas been used to some extent among the Germans, but it is found to be very unreliable when taken out of water and applied, dropping off the patient when only half gor ged, but when covered with water will gorge to its full extent. I believe that this is the only instance known of utilizing our native leeches. Tis German and French government were the first to offer large premiums for the encouragement of leech culture, but many year elapscd until a French fishorman, named Berchade, met with entirc success, and at the same time accumulated quite a fortune, as leeches and brought high prices.

In 1841 a Mr. $\mathrm{H}$. Witte estab lished a small leech farm in Kent avenue, Williamsburg, L. I. In course of time this sniall establishment was abandmed, and one of thirteen acres was established nea Newtown, L. I., and to bim I amindebted for thie following information and description of the only leech farm in America. The breeding ponds consist of oblong squares of one and a balf acres each. The hottoms of these ponds are of clay, the margins of peat. In June the eeches begin forming their cocoon

* By permission from the "History of New York," by Mrs. Martha J. of canal navigation, with numerous well executed plates from designs or $n$ in the peat margins of the pond. These so called cocoons Lamb. A. S. Barnes \& Co., publishers : New York and Chicago. bis own. He also about the same time, in England, patented a mill for are very curious olj,jects, consisting of a frothy mass of gela + The statement that Robert Fulton was present at this trial of Fitch's sawing marble. for which he received the thanks of the British Society tin material of the size shown in the illustration. Throug b \begin{tabular}{l|l} 
steamboat on the Collect, in 1796, is an error, he being in England at that & for the Promotion of Arts and Commerce and an honorary medal. In \\
date, thoroughly absorbed in the study of Watt's steam ensine and \\
$179 \%$ he passed over to Paris, with the intention of bringing to the notice
\end{tabular} canals; he that year published in London a treatise on the improvement of the French Government a submarine torpedo and torgedo boat. 
cocoon close, and the gelatinous material becomes more dense and glue like. From each cocoon from thirteen to twenty-seven young leeches are developed. The young are the cocoons early in September. At first they are no thicker than a pin, but at that early age are capable of cutting through the skin of a horse. At the end of three years these through the skin of a horse. At the
leeches are ready for the market.

The greatest enemies to young leeches are musk.rats, water rats, and water shrews, who dig the cocoons out of the soft peat breeding margins. Next to ratsandshrewsis over-
heating of the peat or the water of the pond. In fact, nothheating of the peat or the water of the pond. In fact, nothing is so fatal to leeches as a too high temperature. Mr. Witte says he has bad leeches frozen in solid ice, but by perature of the water the leeches sustained no injury. The depth of the water in the ponds during summer is three feet, in winter time the depth of the water is increased to avoid freezing.

The leeches are fed every six months on fresh blood placed in thin linen bags, which are suspended in the water. The leeches, as soon as they smell the blood, assemble from all
parts of the pond, and attaching themselves to the outside of the bag suck the dissolving coagulated blood through the linen. Digestion proceeds very slowly in the leech, and more than a year will elapse before all the blood is digested in a fully gorged leech, during which time the blood remain-
ing undigested in the stomach of the leech is in a fluid state, as if just taken in. The excremental deposits are of a grassas if just taken in. The excremental deposits are of a grass-
green color. The best substance for packing leeches in is green color. The best substance for packing leeches in is
the peat of their natural ponds made into a stiff mud. Water the pent of their natural ponds made into a stiff mud. Water
containing tannin, tannic acid, lime, salt, or brackish water must be guarded against always; iron is not objectionable but is an advantage in small quantities.

The demand for leeches in the last few years has somewhat fallen off in the Eastern and Southern States. The Western States and California are now the heaviest buyers. Mr. Witte's sales alone average a thousand a day. The

number of leeches importe

The custom of stripping and salting leeches, to cause them this must remain the case so long as orchid hunting is stach a to disgorge after having been applied, has passed away, as costly and dangerous employment.

many well established cases have occurred of infectious dis eases having been communicated on the application of the same leech to a second party. A very popular error exists that a leech when applied takes only the bad blood (whatever that may be) and rejects the good; this is a mistake. With a leech blood is blood, be it the cold blood of a fish or the warm llood of a human being, no matter how diseased that human being may be. So long as blood is fresh and not tainted or putrid the leech will thrive on it. A friend of mine, who was the proprietor of a large leech-breeding estab. mine, who was the proprietor of a large leech-breeding estab-
lishment at the foot of the Harz Mountains, when wishing to feed his leeches was in the habit of hiring poor laborers, at six cents per day, to stand in the water for half an hour nearly up to their thighs

In the marshy lands of Roumania the wild leeches are cap. tured by means of men entering the water and allowing the wild leeches to fasten on to their naked bodies. The leech fishers then strip them off after reaching the shore.

\section{How to Keep Leeches.}

Take any wide mouth bottle that will admit the hands and fill it about two-thirds full of what is known as "Excelsior" (such as is sometimes used in upholstering and making cheap mattresses), wash the "Excelsior" with warm water and pour it.off; then pour in cold, soft water enough to cover,
and put in the leeches, tie a piece of thin cloth over the top change the water once a month, and occasionally set the bot tle and contents in the sun.

I have used this method for a number of years, and I do not remember ever finding a dead leech. It has certainly proved better than any jar, sponge, rusty nails, earth, or anything else I ever tried, and has the recommendation of
being cheap and easily attended to.-James S. Talbot, in New Remedies.

\section{Ret urn of an Orchid Hunter.}

\section{The Mastod on in Recent Times.}

Prof. John Collett, Ph.D., State Geologist of Indiana gives some statistics in relation to the mastodon, that dis-
pels the notion that these animals did not live in recent pels the notion that these animals did not live in recent
imes. Arcliæologists who argue the great antiquity of man upon this planet, based upon the fact that his remains have been found with those of the mastodon, will be compelled from page 385, Geological Report for 1880. Professor Col ett says:

Of the thirty individual specimens of the remains of the mastodon (Mastodon giganteus) found in this State, in almost animal proved to be in a greater or less condition of decay The remains have alwass been discovered in marshes, ponds, or other miry places, indicating, at once, the cause of the death of the animal and the reason of the preserva dition are found at the summit of the glacial drift or in "old beds" of rivers which have adopted a shorter route and lower level, consequently their date does not reach be yond the most recent changes of the earth's surface; in fact,
their existence was so late that the only query is, . Why did their existence was so
they become extinct?

A skeleton was discovered in excavating the bed of the canal a few miles north of Covington, Fountain County, bedded in wet peat. The teeth were in good preservation,
and Mr. Perrin Kent states that when the larger bones were cut open the marrow, still preserved, was utilized by the bog cutters to "grease" their boots, and that chunks of perm-like substance, $21 / 2$ to 3 inches in diameter (adipo-
cere), occupied the place of the kidney fat of the monster During the past summer of 1880 , an almost complete skele ton of a mastodon was found six miles northwest from Hoopston, Iroquois County, Ill., which goes far to settle definitely that it was not only a recent animal, but that it On several occasions during the past year or two our survived until the life and vegetation of to day prevailed. and interesting information touching the natural history of long, 22 inches in circumference at the base, and in thei the Amazonian forest regions communicated in his letters to water-soaked condition weighed 175 pounds. The lower the World. Mr. Morris litely returned to this city, bringing jaw was well preserved with a full set of magnificent teeth, a large number of rare and valuable orchids, which he has and is nearly 3 feet long. The teeth, as usual, were thickly a large number of rare and valuable orchids, which he has and is nearly 3 feet long. The teeth, as usual, were thickly
collected for Mr. Erastus Corning, of Albany, N. Y., whose enameled, and weighed each from 4 to 5 pounds. The leg. collected for Mr. Erastus Corning, of Albany, N. Y., whose enameled, and weighed each from 4 to 5 pounds. The leg,
collection is valued at more than $\$ 100,000$, and is considered bones, when joined at the knee, made a total length of $51 / 2$ collection is valued at more than $\$ 100,000$, and is considered bones, when joined at the knee, made a total length of $51 / 2$
the finest in the United States. Mr. Morris expects to return feet, indicating that the animal was no less than 11 feet to his orchid hunting in South America, probably in Colum- high, and from 15 to 16 feet from brow to rump. On in-
bia and Equador. With the genuine explorer's feeling he specting the remains closely, a mass of fibrous, bark-like bia and Equador. With the genuine explorer's feeling he specting the remains closely, a mass of fibrous, bark-like and I want to get off the beaten track. When I come across animal's was found between the ribs, filling the place of the an empty beer bottle hung up as an ornament in an Indian hut it make: me feel as though I was too near home."

Although the Amazon has been well explored, people have (and shells were observed no idea of the richness in gums, herbs, and rubber of the and collected, which were kindly determined by Dr. F. country through which its tributaries flow. In trading Stein, as follows:

along these rivers the Americans are far behind the English 1. Pisidium, closely resembling P. abditum, Halderman.
and French, although goods of American manufacture are 2. Valvata tricarinata, Say. 3. Valvata, resembling considered the best and are most expensive.

Besides the orchids Mr. Morris brought a great quantity of herbs used in making the poison Wourali, with which ' Illinois, Inell bearing animals prevail all over the States of experiments are to be made, as it is thought to be valuable sively that, however other conditions may differ, then ant mal and vegetable life, and consequently climate, are the same now as when this mastodon
and clay.-Clinton (Wis.) Herald.

\section{How Cattle a re Killed for New York Market.}

In the city of New York there are two large abattoirs or slaughter houses. On the east side of the city there is a collection of several of these establishments, which occupy the blocks bounded by East Forty-third street, First avenue, blocks bounded by East Forty-third street, First avenue,
East Forty-sixth street, and the river front. The totalnumber of beef cattle slaughtered here last year amounted to bout 100,000 head.

At the foot of West Fortieth street is what is called the West Side Abattoir, which is the largest establishment of the kind in the city. Its dimensions are 425 feet in length on uniform depth of 200 feet. The annual kill of beef cattle here is 2,200 head per week, or about 115,000 a year.

At Jersey City, across the river from New York, is situated another large establishment of this kind. It is not only a slaughter house, but the receiving point for the greater portion of the cattle coming into New York. It is very favorably situated, being not more than a mile by water from any of the European steamship wharves, and cattle for export can be shipped by boat from the abattoir direct to the side of the vessel. For this reason it is the principal place from which the live stock export traffic is done. The stock yard covers several acres, and is divided into large pens, partly covers several acres, and is divided into large pens, partly
roofed over, with water troughs and hay racks running along roofed over, with water troughs and hay racks running along
the sides. They afford accommodation for about 3,000 cattle, and the charge per head for each animal entering the yard, no matter how long or short may be the period of its stay, is 40 cents. During the time they are kept in the yard they are fed at the owner's expense. The slaughter house proper is a building 250 feet front by 300 deep, but with the
offices and other additions the buildings cover an area of 270 by 390 feet.

When the company which controls thisabattoir first started in business, in October, 1866, their establishment was at Communipaw, and in 1867 their receipts were 79,829 catle, 456,939 hogs, 16()$, 247$ sheep, of which 16,791 cattle, 423,512 hogs, and 143,639 sheep were killed on the premises. The
export trade in live stock brought a large increase in the reexport trade in live stock brought a large increase in the re-
ceipts, and in 1875, the year after they took up their present ceipts, and in 1875 , the year after they took up their present location at Harsimus Cove, Jersey City, they received 78,550 cattle, $640,149 \mathrm{hogs}$, and 685,724 sheep; of these,
78,894 cattle, 543,919 hogs, and 431,241 sheep were slaughtered on the premises. From this time on the arrivals have continued to increase, until last year they reached have continued to increase, until last year they reached
368,298 cattle, 952,371 hogs, and 634,191 sheep. The 368,298 cattle, 952,371 hogs, and 634,191 sheep. The
slaughter of beef cattle, however, had fallen to 43,758 , while laughter of beef cattle, however, had fallen to 43,7
hat of bogs was 940,200 , and of sheep 630,700 .

The cattle coming into New York average from 700 pounds 800 pounds in weight, and at 10 cents per pound, abou the usual figure, bring $\$ 70$ to $\$ 80$ each on the hoof. The method of killing is essentially the same in all the New York laughter houses. A rope is fastened around the animal's hind legs, and he is lifted off his feet by means of a block just touching the floor. His throat is then cut with a large, harp knife, and his death is speedy and comparatively free from pain. Three workmen, a dresser and two assistants, can kill, flay, cut up, and dress an animal in about twenty minstes, and they slaughter eighteen to twenty head daily, for which they get 59 cents per head.

After the slaughtering for the cany is at an end all the buildings are flushed out with water pumped from the river y steam, and then carefully mopped over, so that no sign of refuse of any kind is perceptible-in fact, the floors, whic re laid with an incline from the sides to a gutter in the middle of the houses, are as clean and white as the decks of a
ship after they have been holystoned. - Shoe and Lecther Reporter.

\section{Source of Bad Taste in Croton $W$ ater.}

Nearly every spring the users of our city Croton waterare "larmed by an unpleasant "fishy" or "cucumbery" or "woody" taste, which lasts sometimes for weeks. This season it was particularly offensive. At a late meeting of the
New York Microscopical Society, Mr. J. D. Hyatt called ttention to the fact that in early spring. D. Hyatt called mountain brooks which feed the lakes become covered with gelatinous layer of minute vegetable organisms known as iatoms, sometimes to a thickness of a quarter of an inch. very little of this jelly mass placed in a vessel of water will soon impart the same odor to the water as is observed the Croton. Mr. Hyatt concludes that as soon as the jelly egins to disappear from the streams, which occurs when it attains a certain stage of growth, the same odor will be imparted to the entire body of water which flows to this city. If this is true no trace of the cause of the odor would be found by microscopical examination of the water in the city at such long distance from its source. Mr. Van Brunt said his observations confirmed this view.

\section{The Ancient Cypress near Sparta.}

The celebrated cypress tree that had stood near the city of Sparta, Greece, for over 2,800 years, and was described by Pausanias 400 years before the coming of Christ, has been destroyed by a band of strolling gypsies, who camped be neath it and left their fire burning. It was 75 feet high and 10 feet in diameter near the ground. The poople of Sparta greatly mourn its loss. 
The Mississippi River and the Grain Trade. Mexico, and Holland, while the importations from Java and At the last meeting of the New York Board of Trade and Sumatra show a large increase. The tea trade of the yea Iransportation some significant figures were given as to the was especially unprofitable to those directly engaged in th relative cost of transporting grain from the West to Liver- importation of China teas. The unprecedented figures of Orleans. It was stated that rain can be shipped from St. hides, exclusive of Calcutta hides, or an excess of 900,000 Louis 10 Liverpool, by way of the river, for 17 cents a over the figures of 1879 . The wine and liquor trade was Louis to Liverpool, by way of the river, for 17 cents a over the figures of 1879 . The wine and liquor trade was
bushel; the rate by way of New York is $291 / 2$ cents. The remarkable for its prosperity and the few disasters bushel; the rate by way of New York is $291 / 2$ cents. The remarkab
rates from St. Paul, Minn., show a difference in favor of reported.

New Orleans of $151 / 2$ cents a bushel.

Under these conditions the increasing tendency of shippers of grain in the Mississippi valley to choose the southern route is not surprising. During the year ending August 31,1879 , the exports from New Orleans were 4,617,825 bushels of corn and 1,868,084 bushels of wheat. For the year ending and 5,344,510 bushels of wheat. The total increase for the year was nearly nine million bushels. The increase for the coming year is likely to be still greater, as several barge lines and many new barges have been added to the grain fleet of and many new barges have been added to the grain fleet of
the Mississippi River for this season's trade. By this plan the Mississippi River for this season's trade. By this plan
one towing steamer is able to guide down the river a raft of barges carrying from eight to twelve hundred car loads of grain. The cheapness of the river route much more than compensates, as we have seen, for the increased length of the ocean trip. The passage from St. Louis to New Orleans is made in little over a week. The amount of the barge traffic
already in progress may be estimated from the following figures given in the St. Louis Republican of April 8, with figures given in the St. Louis Republican of April 8, with
reference to the carrying capacity of barges then about to start for New Orleans:

Steamer Iron Mountain and five barges with 220,000 bushels wheat and 50,000 bushels corn; Oakland and si barges, with 50,000 bushels wheat, 200,000 bushels corn, and 25,000 bushels oats; and the Bigley and four barges, with 40,000 bushels wheat and 100,000 bushels corn, making a total shipment for the week of 680,000 bushels grain, which by railway transportation, at 500 bushels to the car, would require 1,370 cars, and estimating 20 cars to the train, would make up 69 freight trains and employ about 400 train men
The amount of wheat carried will be 310,000 bushels, corn The amount of wheat carried will be 310,000 bushels, corn
350,000 bushels, and 25,000 bushels oats, to say nothing of the package freight, which will be large."

The reduction of the cost of transportation to Wester Europe of ten or fifteen cents a bushel must have the effect of vastly increasing the power of our Western wheat grow ers to compete successfully with those of Hungary and Russia, and thereby largely increase the European demand for American grain. In this way the development of the river American grain. In this way the development of the river
route (thanks to the successful working of the jetty improveroute (thanks to the successful working of the jetty improve-
ments at the mouth of the Mississippi) cannot but prove advantageous to the farmers of the Mississippi Valley as well as to the merchants of New Orleans.

The effect upon the commerce of the Atlantic States is no at first so promising, unless by the improvement of railway, canal, and lake carriage the cost of transporting grain from the interior to the seaboard may be so reduced that the prim ary advantage of the river route can be overcome.

If it should prove that the East and West, water and rail routes are unable to compete with the Mississippi in the transport of bulky and cheap agricultural products, it by no means follows that their profitableness will be seriously im paired in the long run. The prosperity which must come
to the interior through the establishment of a cheaper way to market for its surplus products must tend to increase rapidly the purcbasing power of its people and their dispositio to purchase largely those commodities which compress more value into a little space and inevitably demand direct and rapid carriage. And the merchants and transporters of the seaboard may possibly find the farmers of the interior, owing to an increased though diverted grain trade, much more profitable as customers than they ever have been. Part of a great traffic may be worth more than the whole of a lesse traftic

\section{The Commerce of New York.}

The twenty-third annual report of the New York Cham ber of Commerce, just presented, covers the trade of the year 1880. In reviewing the imports of the year, the sugar trade is first considered, the course of this staple being regarded as a sure indication of the general condition of the country. The consumption of sugar was 819,000 tons, as against 743,000 tons in 1879 . Of this quantity Louisiana against 743,000 tons in 1879 . Of this quantity Louisiana furnished 89,000 tons, the remainder being drawn from for
eign sources. If to this consumption be added that of sugars eign sources. If to this consumption be added that of sugars
from beet root and maple groves the total is swollen to from beet root and maple groves the total is swollen to
900,000 tons. New York continues to be the chief port of receipt and distribution for this large trade, taking 570,000 tons against 506,000 tons the previous yea

The consumption of foreign molasses, owing to the fallin off in the yield of the West India sugar crop, decreased from $34,500,000$ gallons in 1879 to $33,100,000$ gallons in 1880 . The crops of Louisiana and Texas yielded 12,000,009 gallons, making the total consumption for the year about $45,000,000$ gallons. The trade, like that of sugar, has been profitable. The history of the coffee trade for 1880 will be ever memor- in diameter and quarter of an inch thick. The gold medals are able for the lesson it has taught of the danger of attempting 20 carets fine, and weigh $71 / 2$ ounces. The diplomas accom to force up the price of a great staple by monopolizing the panying the medals are handsomely lithographed. The list supplies. Consumption, however, was not seriously dis- of American awards includes, in addition to the great prize. turbed by the specuiation, the total amount being 176,000 of $\$ 2,000$, taken by the U. S. Commission of Fish and Fishtons, against 184,000 tons in 1879 , a decrease of about $41 / 2$ eries, eight gold medals, sixteen silver medals, and twelv decrease in the receipts was from Brazil, the West Indies orable mention.

Concerning the exports of this country, the report says

fhe provision exports from all ports of the United $61,000,000$ pounds in 188 . The entire as $\$ 61,000,000$, against a value last year of $\$ 58,000,000$. $16,000,000$. Of this trade New York had over $\$ 7,000,000$

The Water Power of the Atlantic coast.

In his annual report, just submitted, Chief Engineer McFadden, of the Philadelphia Water Department, asserts hat the available water power of the Schuylkill and of all rated. of the Schuylkill to be equal to the pumping of a daily averof the Schuylkill to be equal to the pumping of a daily aver-
age of 100000,000 gallons. Mr. McFadden undertakes to show that the real power is not balf as great, all the wate being used ail the time.

The amount pumped by the machinery at Fairmount, run ning 54 per cent of the time, was a daily average of 21,551 , 630 gallons. "Had there been power enough to drive the machinery 100 per cent, or all the time," he continnes, " it could not possibly bave pumped more than $40,000,000$ gallons per the machinery at Fairmount would use and exhaust the power of the river if it was subjected to a steady and equable power of the river if it was subjected to a steady and equable
flow by impounding the storm waters. Of course duplicate water-power works at Roxborough, by using the power twice first at Roxborough and a second time at Fairmount, could be made to double this amount."

The pumpage for last year amounted to $21,120,792,380$ gallons, an increase of 6 per cent over that of the previou The value of the entire export of lard was nearly $\$ 28,000,000$ an increase of $\$ 5,000,000$ over the previous year. Noticeable
also is the export from New York of oysters to the value of $\$ 400,000$, out of a total exportation valued at $\$ 550,000$. O 000 value exported, New York sent $\$ 91,000,000$. The shipments of crude and refined petroleum were $8,000,000$ bar to be in excess of the demand about 20,000 barrels per diem. The tide of immigration brought to this country during the
Jear 457,257 persons, of whom 327,371 were landed at port. Of the latter, 104,000 were from Germany, 66,000 rom Ireland, 35,000 from Sweden, and 34,000 from England.

\section{The Shingle Product.}

In recent issues the Northwestern Lumberman has give the amount of which is something stupendous, as will be een in the following recapitulation of the output of the pas gs:

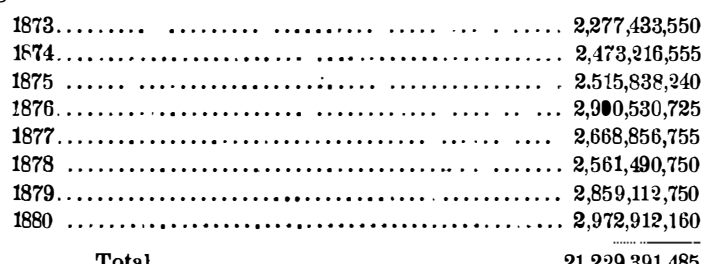

It is estimated that something between $800,000,000$ an his country

Previous to 1845 the manufacture of shingles in the United "tates was almost, if not wholly, confined to the article of
"rived " or " breasted," terms applied to shingles made by hand with a drawing knife, involving a waste of fully three quarters of all the timber which it was intended to convert at the butt, and one-eighth inch at the point, and were made nly from the finest pine, cedar, or cypress, the latter bein wholly manufactured in the swamps of Virginia and other
Southern States. About that date steamed cut shingles had been introduced, but never attained a wide spread reputatio $r$ market, because of imperfections in the manufacture. ot far from 1845 sawed shingles were introduced, and their imber could be utilized in based upon the fact that coirse of the product cheapened. They were not at first received with favor, but have rapidly grown in public estimation unti they have almost wholly superseded all others. With th ber, hemlock was utilized for some time in the East, but ha in late years been but little used.

The shingle cut of eastern Michigan and Huron shore being shipped to the East and Southeast, where no smalle size is salable. A thousand feet of logs is calculated to coarser grades which have narketable shingles, besides the shipment. The cut of western Michigan, Wisconsin, and the Mississippi district is wholly of $16 \mathrm{inch}$, for the demands
of the Western market and the less stringent inspection as to quality enable the manufacture of from 7,000 to 8,000 shingles from 1,000 feet of logs.
s.

\section{The Jillization of Blood, Bones, etc.}

In our city abattoirs very little of a slaugh tered animal is Inowed to go to waste. The hoofs are sold for glue stock, bring 1 cent to $11 / 2$ cents per pound. The tallow is purpose, rendered at the aboutoirs, and buing per pound. What is called " hot fat," that is, fat taken from
pals per pound. What is called " hot fat," that is, fat takenfrom
the breast and kidneys of the animal while it is yet warm, the breast and kidneys of the animal while it is yet warm,
is sold to oleomargarine manufacturers at $4 \frac{11}{2}$ cents per is sold to oleomargarine manufacturers at $4 \frac{1}{2}$ cents per
pound. The bladder, wizen, reed, and bung gut are sold pound. The bladder, wizen, reed, and bung gut are sold for about 8 cents a set, and made into skins for wrapping off it and canned, while the b 30 cents, and the meat is taken flesh tail, worth 5 cents, is made into soup, and the hair tail, which is used for making mattresses, or mixed with lime and sand for building purposes, is sold at 4 cents. Horns, ' and sand for huilking purposes, is sold at 4 cents. Horns, tons, handles for cutlery, etc. The blood is dried by steam which separates the water from it, and then baked in a drymg machine and sold for sugar refining and fertilizing purposes. Of late years it has also been manufactured into bu tons by means of a chemical process. A number of consumptives come to the slaughter houses daily, and drink the warm blood from the freshly-killed animal with very beneficial results in many cases. The stomachs are used for tripe, and bring $12 \frac{1}{2}$ cents to 15 cents each. The tongue is worth 50 cents to 60 cents, and is usually smoked. The heart and liver together bring 30 cents, and although some times used for human food, are generally sold for cats' and dogs' meat.

\section{Artesian Wells in New York.}

The number of artesian wells in this citysteadily and rapthe past year. Their depths range from 200 to 2,000 feet
the and the flow ranges from 1,000 to 2,090 barrels a day. Thes wells are used mainly by brewers and other large manufac turers who require a large amount of water, and who find he artesian well water economical both from its cheapness and its coolness, which enables them to dispense with much ice. Usually the wells are vertical. In one instance seven holes were drilled in different directions and at differen angles, only one being vertical. The boring was carried to
a depth of about 260 feet on the average, the longest at an a depth of about 260 feet on the average, the longest at an
angle being 457 feet deep. Water was struck in all the borangle being 457 feet deep. Water was struck in all the bor-
ings, and an abundant supply has been obtained continuings, a
ously.

\section{Improving American Tea.}

Recently on receiving a number of packages of American tea from the experimontal tea farm in South Carolina, Com missioner Le Duc invited a number of tea dealers in Balti more and Washington to test the quality of the crop. They pronounced it very good tea, and said it compared favorably place bad a weedy flavor. This year the same defect only barely perceptible, the result being due to cultivation. By next year it is thought it will have disappeared entirely. It is even now only perceptible to the taste of experts. Let ters from Mr. Jackson, the gentleman in charge of the tea farm, comment in very favorable terms upon the healthy appearance of the plants and the prospect for excellent results.

\section{The Value of Good Brakes.}

Recently, while the steamer State of New York, from this city to Hartford, Conn., with about two hundred passengers, was passing the drawbridge across the Connecticut River, near Saybrook, a heavy freight train ran upon the bridge at considerable speed. The engineer had been misled, perhaps, by a confusion of lights, and very nearly ran his train into the draw to the destruction of the steamer. The engin when the train siopped was within 30 feet of the draw.

A Heavy Woman.-Mrs. Charles Ballou, known as the Mammoth Queen, died April 8. Her weight had been 400 pounds. The coffin was $6 \frac{1}{2}$ feet long, 3 feet wide, and 20 inches deep. 